\title{
Effectiveness Of Administrative Sanctions Enforcement In Code Of Notary (A Studi In Cirebon)
}

\begin{abstract}
Maulana Agung ${ }^{1}$, Ahmad Mustarsidin ${ }^{2}$ and Gunarto ${ }^{3}$
Abstract. In running position, besides bound by the Law Notary, the Notary is also bound by the Notary Code, created by the organization Indonesian Notary Association (INI). Notary supervision carried out by the Minister of Law and Human Rights by establishing a Notary Supervisory Council, and the Organization of Indonesian Notary Association established the Honorary Board of the Notary. The purpose of this study is to analyze the type of Code violations that occurred in Cirebon, analyze the types of sanctions that are applied, and analyze the effectiveness of administrative sanctions were applied in establishing the Notary Code. The results showed of some types of provisions Notary Code, violations that occurred in the district of Cirebon include price competition, and the use of intermediaries in getting clients. Based on the results of this study concluded that several factors causing these violations such as contradictory rules with conditions on the ground, a notary referred to as public official, but are forbidden to promote themselves, as officials, but not paid by the State as public officials more, while the number of Notaries every year increases, there is competition between them, caused intentionally or not unethical Notary. In addition, the sanctions only administratively, causing frequent violations and lack of deterrent effect, Keywords: Code of Notary; Effectiveness; Sanctions.
\end{abstract}

\section{Introduction}

As a rule of law, one of the most important tasks for the government is to provide and ensure a sense of legal certainty for their peoples. In certain areas of the task by the government through the Law given and entrusted to the Notary, as Public Notary is the official authorized to make an authentic deed and have more authority as referred to in this Act, or under any other laws. ${ }^{4}$

Instead people must also believe that the Deed made that provides legal certainty for them, according to the wording of Article 15 paragraph 1 of Act No.30 of 2004 concerning Notary. "Notary authorized to make the authentic act on all deeds, agreements and statutes that are required by the rules and regulations and / or desired by the stakeholders to be stated in an authentic deed, guaranteeing the creation date of the deed, saving certificates, giving grosse, copy and quotes deed, all along the deed was not also be assigned or excluded to other officials or any other person specified by law ".

In carrying out his duties of the Notary not only carry out the work mandated by legislation alone as well as running a very important social function that is responsible for carrying out the trust given it serves the general public, because it Notary must cling to the Notary Code. The code of ethics is formed by a Public Notary legitimate organization and the only one recognized by the Act, namely organizational Indonesian Notary Association (INI), a

\footnotetext{
1 Master of Notary's Student, Faculty of Law, Universitas Islam Sultan Agung, email agungmaulana369@gmail.com

2 Students of Master of Law, Faculty of Law, Universitas Islam Sultan Agung email ahm.mustarsidin@gmail.com

${ }^{3}$ Professor of the Faculty of Law UNISSULA Semarang, Indonesia.

${ }^{4}$ Article 1 line (1) of Act No.2 of 2014 on the Amendment Act No. 30 of 2004 concerning Notary office
} 
set of rules created to regulate and maintain the honor and dignity of the Notary in their profession.

Article 67 of Act No.30 of 2004 concerning Notary, mentioning that the oversight of the Notary by the Minister in this case is the Minister of Justice and Human Rights of the Republic of Indonesia to establish the Assembly of Trustees consists of Assembly Supervisory Center, Council of Trustees of Regions and the Assembly of Trustees area, whereas in the Indonesian Notary Association Society Organizations (INI) formed Notary Honorary Council.

Based on the description above, the writer interested to do research and raised it in this article with the title: Effectiveness Of Administrative Sanctions Enforcement In Code Of Notary (A Studi In Cirebon).

As for problems formulated is any type of offense committed by a Notary in Cirebon, what kind of sanctions are applied, and how the effectiveness of the sanctions applied in the enforcement of the Code Notary in Cirebon.

\section{Research Methods}

The method used in this research using empirical juridical approach (socio legal research). ${ }^{5}$ Juridical Empirical research is conducted legal research by examining primary data obtained directly from the public, ${ }^{6}$ which in this case regarding the sanctions adopted by the Supervisory Council of Notaries in the enforcement of the code of ethics Notary in Cirebon.

In empirical legal research, the source used as the primary source of data is the main and secondary data sources as supporting data. Data collection techniques, namely, the first primary data by interview. An activity debriefing interviews with respondents who used sources freely guided, that is only outlines the questions which address the issue by using a data collector in the form of a list of questions with open systems to provide freedom for the Speaker to answer questions according to his opinion. Informant in this research is the Chairman of Supervisory Council of Regency of Cirebon, Chairman of the Indonesian Notary Association (INI) Cirebon, Chairman of the Land Deed Official (IPPAT) Cirebon, and 2 (two) Notary. Furthermore, secondary data by collecting data Library, consisting of primary legal materials such as Act No.30 of 2004 jo Act No.2 of 2014 concerning Notary, Regulation Notary Code Results of the Extraordinary Congress Banten May 30, 2015, Council Regulation Honor Center Indonesian Notary Association (INI) No. 3 of 2017 on Procedures for Investigation Over Alleged violations committed by members of the Association and other people (who are running the Notary). Furthermore, secondary law, is composed of materials that are closely related to the primary legal materials and can help analyze and understand the primary legal materials, including literature books, magazines, journals, scientific research relating to the cases in this study.

The data were analyzed using qualitative and quantitative analysis methods. Qualitative analysis was performed on the primary legal materials, secondary law, and tertiary legal materials which include principles, rules-rules of law, and the laws that apply in the relation with the code of conduct Notary and analyzing secondary data (Normative) and compared with the data obtained from research field (Empirical) either in the form of data analysis and subsequent figures compiled inductively.

\footnotetext{
${ }^{5}$ Anis Mashdurohatun et all. Factors Causing Banking Cyber Crime in Indonesian , International Journal of Economic Research Volume 14 Number 152017 http: www.serialsjournals.com p. 295

6 Soerjono Soekanto and Sri Mamudji, 2001, Penelitian Hukum Normatif suatu Tinjauan Singkat, Jakarta: Raja Grafindo Persada.
} 


\section{Discussion}

\subsection{Violations Of The Code Of Conduct Type of Notary in Cirebon}

Notary Code by professional organizations office of Notary Results Extraordinary Congress of Indonesian Notary Association (INI) on 28 January 2005, held in Bandung, under Article 1 paragraph (2) are as follows whole kaedah moral specified by the Society Indonesian Notary Asosiation who hereinafter called the "Association" based on the decision of Congress Association and / or defined by and regulated in the legislation governing it and that applies must be obeyed by each and every member of the Association and all those who carry out duties of office as Notary, including Acting Notary, the Notary Substitutes and Special Substitute Notary.

Thus the Notary Code of Conduct is the guidance, counseling, morals or decency guidelines Notary well as private and public officials appointed by the government in order to provide services to the general public, especially in the field of deed. ${ }^{7}$

Among the ethics that must be held by a Notary in performing its duties and obligations, are: ${ }^{8}$ that the Notary must be aware of their obligations, working alone, to be honest, impartial, and full of a sense of responsibility; Using an office that has been established in accordance with the law, do not hold representative offices, and not using intermediaries; Do not use mass media promotional nature; Should put up a sign signboard according to the size of the force.

In addition, in providing services to clients, Notary bound code of conduct including the following: Providing legal services to people who need its services as well as possible, giving information on the law so that the public aware of their rights and obligations as citizens and community members, providing services to members the poor with free of charge; Prohibited detain a person files with the intention of coercing him a deed on notaries who hold the bundle, are barred from another person or party tool to simply sign the deed made by someone else as artificial Notary deed concerned.

Based on the research results, ${ }^{9}$ some types of violations that sometimes done by a Notary in Cirebon regency, is the price competition and the use of intermediaries in getting clients. Such conditions usually occur due to the need Notary to get as many clients as possible in order to use their services, since it can not be denied, Notary although referred to as a public official, but in practice, they do not get a salary / income as Public Officials of other salaried by the state, so the tendency to earn the income they sometimes have to do a variety of ways to bring in clients that want to use their services, while on the one hand they are bound by a set of regulations and codes of conduct Notary that limit their movements to get clients.

\subsection{Type Sanctions Applied to the Notary Code Violations}

Notary supervision under Article 67-81 UUJN, which essentially oversight made by the

\footnotetext{
7 Liliana Tedjosaputro, 1995, Etika Profesi Notaris Dalam Penegakan Hukum Pidana, Bigraf Publishing, Yogyakarta

${ }^{8}$ Abdulkadir Muhammad, 1997, Etika Profesi Hukum, Citra Aditya, Bandung.

${ }^{9}$ Ibn Artadi, Saleh Bafadhal, Ahmad Nawawi, interviews, chairman of the MPD, Chairman of the INI, Chairman IPPAT and Notary in Cirebon, dated June 25, 2018
} 
Minister and in carrying out the supervision of the Minister to appoint the Supervisory Council, which consists of the Supervisory Council of Regions, Regional Supervisory Council and the Supervisory Council of the Center. In the Organization of Indonesian Notary Association (INI) in article 12 of the Articles of Association THIS Association, noted that in terms of supervision and oversight conducted by the Notary Code of Honor Board of the Notary.

Article 70 UUJN regulates the authority MPD such as: Holding a hearing to examine the alleged violation of the Code of Conduct Notary or violations of the implementation of office Notary, conduct an examination of the Protocol Notary Periodically 1 (one) time in 1 (one) year or any time it deems necessary, give permission to leave for a period of up to six (6) months, set Substitute Notary by considering the proposal Notary concerned, determine the storage area protocol notaries who at the time of the handover protocol notary are aged 25 (twenty five) years or more, receive reports from the public concerning the alleged violation or breach Notary Code provisions in this law.

The sanctions that can be applied to the Notary who violate the provisions of Act No. 30 of 2004 concerning Notary, in accordance with Article 85 UUJN is in the form of an oral reprimand, written reprimand, suspension, dismissal with respect, or dishonorable discharge.

Based on the results of research, types of penalties for violation of code of ethics Notary is an administrative sanction, namely in the form of verbal warning and a written, this is done because of the type of violation that occurred is still relatively mild, however, when these violations occur repeatedly will be penalized accumulative, which resulted in the fall of more severe sanctions are sanctions of suspension. And in case of more serious offenses again, it is not impossible Notaries will be subject to dismissal with respect, and a dishonorable discharge from the membership as a member of Indonesian Notary Association (INI). With the dismissal of a Notary from his membership in the INI, does not mean he was dismissed from his post as Notary, He was still able to perform their duties and obligations as a Notary Public. This is why sometimes their code of ethics is not so feared by the Public Notary.

\subsection{Effectiveness of Administrative Sanctions Enforcement of the Code Of Ethics In Notaries}

Effectiveness comes from the word that means something effective done successfully, can also be defined as the provision of use, effectiveness or support purposes. Effective word etymologically means achieving the desired objectives (producing desired result), impacted fun (having a pleasing effect), are actual, real (actual and real). ${ }^{10}$ Effectiveness is how well the work that has been done, the extent to which the results achieved someone / something. $A$ job can be considered effective if done as planned in both output and input. Thus basically effectiveness is the achievement of goals or objectives of a program or activity in accordance with the objectives set in the planning. ${ }^{11}$ It can be concluded that the effectiveness demonstrated the ability to achieve goals that have been set according to prevailing standards. Effectiveness is more oriented to output, as it relates to the achievement of the maximum work relating to the quality, quantity and time.

so the choice to reduce prices or rates of their services lower than other Notary compelled

10 I Nyoman Sumaryadi, 2005, Efektifitas Implementasi Kebijakan Otonomi Daerah, Citra Utama, Jakarta

${ }^{11}$ Zaenudin, M, 2017, Efektifitas Penerapan Sanksi denda Terhadap Pelanggaran Lalu lintas di Pengadilan Negeri Mataram, Jatiswara, 30 (3) 
to do, merely for the sake of so clients do not run into another Notary. Furthermore, by using the services of intermediaries in getting clients, this is done because of Notaries are prohibited from promoting in the media in any form, whereas they are confronted with their operational needs in carrying out their work, as they had to support employees who take shelter at the office they are, while the number of Notaries each years of growing, the competition between them is inevitable, and inevitably they must strive by all means to be able to get as many clients as possible.

Factors such as that lead to violations of code of ethics Notary from time to time. While the sanctions are applied only administratively, merely a verbal warning and written, the maximum of a suspension, dismissal with respect, and a dishonorable discharge, and even then they Notary who committed the offense can still be active doing activities as a Notary, so that such violations often happen again, so that sanctions are felt ineffective in upholding the code of ethics Notary.

\section{Closing}

\subsection{Conclusion}

Based on the results of research and discussion of the administrative sanctions in enforcing the Notary Code, it can be concluded that this type of infringement Notary Code that occurred in the district of Cirebon is a form of price competition or the presence of a Public Notary who apply prices tend to be cheaper than the Notary others, and use the services of intermediaries in get clients. The existence of the breach, by the Supervisory Council and the Council of Honor Public Notary given administrative sanctions in the form of sanctions, ie sanctions verbal warning and a written warning. Some factors contributing to the violation of them because of contradictory written rules with field practices that led to the Notary must fight in carrying out its duties and authorities on the one hand, while on the other hand they are tied to a series of rules that restrict them in getting clients. They are public officials, but they are not paid by the State as public officials more, they have employees who need their salary every month also operating expenses each month, requiring them to get as many clients as possible, while the number of Notaries each year is increasing, and certainly there is competition among them, and this will often clash with the code of ethics Notary, so intentionally or not they would violate the Notary code. In addition to this, sanctions of an administrative nature, causes a violation of the Notary Code still frequently occur, so that sanctions are felt ineffective in enforcing the code of conduct Notary.

\subsection{Suggestion}

In the Notary Code enforcement is needed tougher sanctions and will create a deterrent effect for violating Notary. It's also about coaching and debriefing on an ongoing basis to the Notary of the rules relating to the Notary and the code of ethics Notary, to the Notary more familiar with the regulations binding and applies to it, so it is expected that the Notary will grow awareness of it within themselves to obey and comply all the rules. Saran also for stakeholders, in this case the Government in general, and the organization of Indonesian Notary Association (INI) in particular, in order to progress forward in making rules or Notary Code, not to the rules should be able to regulate and curb the behavior of Notaries.

\section{References}


[1] Abdulkadir Muhammad, 1997, Etika Profesi Hukum, Citra Aditya, Bandung.

[2] I Nyoman Sumaryadi, 2005, Efektifitas Implementasi Kebijakan Otonomi Daerah, Citra Utama, Jakarta

[3] Ibn Artadi, Saleh Bafadhal, Ahmad Nawawi, interviews, chairman of the MPD, Chairman of the INI, Chairman IPPAT and Notary in Cirebon, dated June 25, 2018

[4] Liliana Tedjosaputro, 1995, Etika Profesi Notaris Dalam Penegakan Hukum Pidana, Bigraf Publishing, Yogyakarta

[5] Rony Hanitijo Soemitro, 1990, Metodologi Penelitian Hukum dan Jurimetri, Jakarta: Ghalia Indonesia.

[6] Soerjono Soekanto and Sri Mamudji, 2001, Penelitian Hukum Normatif suatu Tinjauan Singkat, Jakarta: Raja Grafindo Persada.

[7] Zaenudin, M, 2017, Efektifitas Penerapan Sanksi denda Terhadap Pelanggaran Lalu lintas di Pengadilan Negeri Mataram, Jatiswara.

[8] The Act of 30 of 2004 jo Act No.2 of 2014 On Notary

[9] Regulation of the Notary Code Extraordinary Congress Banten Results May 30, 2015

[10] Honorary Council Regulation Center Indonesian Notary Association (INI) No. 3 of 2017 on Procedures for Investigation Over Alleged violations committed by members of the Association and other people (who are running the Notary) 